\title{
Habitat Use of Feral Horses and Cattle in Wyoming's Red Desert
}

\author{
RICHARD MILLER
}

\section{Abstract}

Habitat selection by feral horses (Equus caballus) and cattle (Bos taurus) was studied with a series of 16 flights, between November 1977 and April 1979, during which the locations of cattle and feral horses were mapped. The $C 7$ coefficient of association and percent occurrence in different vegetation types and near water sources and ridges were used to compare and describe the habitat use patterns. Cattle and feral horses showed seasonal patterns relative to vegetation types and distance from water sources, and horses showed a seasonal use pattern in regard to areas near ridges. Possibilities for direct competition between cattle and feral horses in the Red Desert were strongest for forage during the fall and in severe winters, and for water during the summer.

Management of feral horses has been a subject of controversy for a number of years, but studies of feral horse ecology have been relatively few. Habitat use by the horses, especially concerning competition with livestock, has been the focus of the controversy, but only 3 studies of feral horse habitat use patterns have been published (Green and Green 1977; Storrar et al. 1977; Salter and Hudson 1978, 1979, 1980). Only 1 of the 3 concerned feral horses in arid areas (Green and Green 1977).

Several researchers have studied feral horse diets (Hubbard and Hansen 1976, Hansen 1976, Hansen et al. 1977, Olsen and Hansen 1977, Vavra and Sneva 1978, Salter 1978). The value of such studies to managers can be increased if the habitat use patterns of the feral horses and livestock are known and correlated with diet study information. Habitat use of feral horses in the Red Desert of southwestern Wyoming between June 1976 and November 1979 was studied in this investigation. The study area overlapped the area for which Olsen and Hansen (1977) reported diets of feral horses, livestock, and big game.

The objectives of this study were to compare horse and cattle use of habitat in the Red Desert and to suggest where competition might be occurring. Welsh's (1975) suggestion that plant communities, shelter and surface water affect the seasonal distribution of horses was my basis for choosing these 3 parameters for the study of feral horse habitat use. The availability of water and forage and the degree of slope are also important determinants of habitat use patterns by cattle (Arnold and Dudzinski 1978, Cook 1966, Valentine 1947, Willms et al. 1979), so the same 3 parameters seemed reasonable for the study of cattle use patterns.

\section{Methods}

The study area was located in Sweetwater County of southwestern Wyoming. Habitat use data were collected on 8 townships (746 $\mathrm{km}^{2}$ ), Ranges 98 to 101 West, Townships 23 and 24 North, along

\footnotetext{
Author is formerly graduate student, Department of Zoology and Physiology, University of Wyoming Laramie 82071, and presently Wildlife Specialist II, Arizona Game and Fish Department, 2222 W. Greenway Rd., Phoenix 85023.

The author thanks Lee Boyd, Val and Ray Hobbs and R.H. Denniston II for their help. Flight time was paid for by: The International Society for the Protection of Mustangs and Burros; Wild Horse Organized Assistance; The Rock Springs District of the Bureau of Land Management; the Department of Zoology and Physiology of the University of Wyoming; Mrs. Margaret Haggard, Mr. and Mrs. C.T. Mallory; R,H. Denniston II; Lee Boyd and Ann Miller.

Manuscript received August 29, 1980.
}

the Kilpecker Dune Field. This portion of the Red Desert lies in the sagebrush-wheatgrass section of the Wyoming basis province (Bailey 1978) and was described by Olsen and Hansen (1977).

The habitat use data were collected on 16 survey flights at approximately 4-week intervals between November 1977 and April 1979. Data for cattle are only available for 13 flights. Cattle locations were not recorded on the November 1978 flight. Cattle numbers were very low in February and April 1979 and were not used for analysis. I used several procedures to minimize bias in these surveys. Because the observer can influence the results of horse counts (Frei et al. 1979), the same observers and pilot were used whenever possible. The same transect lines were used on each flight, with lines 3.2 to $4 \mathrm{~km}$ apart. We used a fixed-wing aircraft (Cessna 172, 182, or 210) and 2 observers as well as the pilot and a recorder.

Locations of cattle and horses from flights were described by vegetation type, distance from water, and distance from ridges. I used the vegetation types described and mapped by the Bureau of Land Management (1978) in compiling the Sandy Grazing Environmental Statement. Ridges were defined as having a slope of $9 \%$ or greater over at least $200 \mathrm{~m}$ horizontal distance.

Weather data from the Rock Springs Airport, $54 \mathrm{~km} \mathrm{SSW}$ of the study site, (NOAA 1977, 1978, 1979) and wind speed data from Medicine Bow wind energy studies, on the study site (Brooks Martiner, Department of Atmospheric Science, University of Wyoming, pers. comm.) were used in regressions. Regressions were run with the SELECT program, which is based on procedures suggested by Hocking and Leslie (1967). This program allows selection of the best subsets of variables by comparison of the amount of variation explained. In effect this program runs a large number of multiple regressions with the same dependent variable. The independent variables used in the regressions were: number of days since the last precipitation; number of days since $6.35 \mathrm{~mm}$ and $12.77 \mathrm{~mm}$ of precipitation; depth of snow on the ground on the day of the flight; average snow depth on the ground over the previous 3 and 7 days; maximum depth of snow on the ground for 1 week; precipitation on the day of the flight; total precipitation of $3,7,14$, and 30 days preceding the flight; maximum, minimum, and average temperature for the day of the flight and for 2 and 7 days prior to the flight; and wind speed. Unfortunately, wind data were available for only 11 flights ( 3 February to 13 October 1978 and 24 February 1979). Wind speed at the time of the flight was used in all regressions. Dependent variables used were the average distances of either cattle or horses from the nearest waterhole or the nearest ridge from each flight.

The C7 cocfficient of association (Cole 1949), which ranges between +1.0 (with total association) and -1.0 (with complete disassociation), was used as a test of association between cattle and horses. This coefficient was chosen for use because it expresses the proportion of the maximum interspecific association which has occurred and allows detection of both association and disassociation (Cole 1949). Data required to determine C7 values are presence or absence of cattle, horses, or both in grid squares. For these tests 3 different quadrat sizes were used $1 / 4$ section, 1 section, and 4 sections, because the coefficient of association varies with grid size 


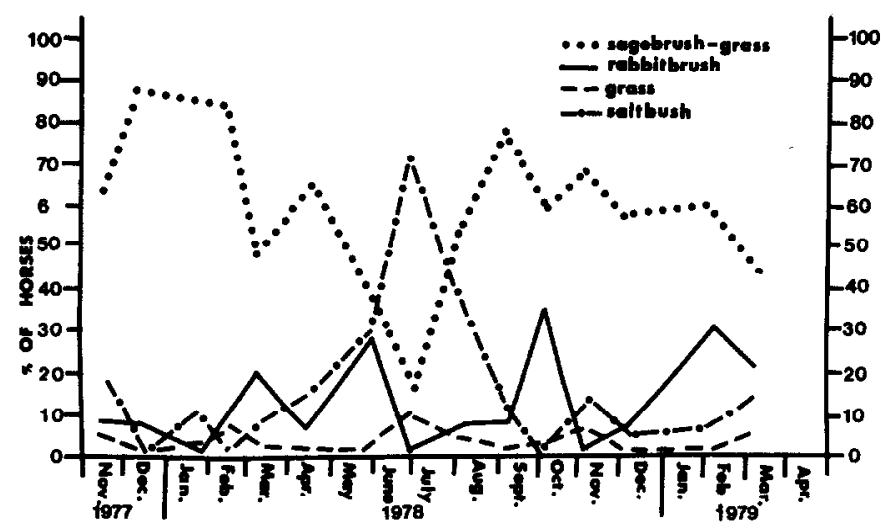

Fig. 1. Percent of feral horses in vegetation types during survey flights.

(Gibbens 1972). The number of cells in a grid which contained neither cattle nor horses was large, prohibiting significant negative association values in some samples. This was especially true for the $1 / 4$ section grid. This problem increased when the study area was subdivided by vegetation type or by areas near ridges or water, because the relative proportion of empty cells increased. The coefficient of association is biased toward animals which tend to leave the main groups, since only the presence or absence of animals within a cell is recorded. For these reasons the majority of habitat use data are presented as percent of the total number of a species which were located within a vegetation type or area.

\section{Results}

Average counts on the 8 townships were 445 horses (range 270 to 660 ) and 188 cattle (range 13 to 414 ) per flight. The average number of cattle was reduced by low counts of 13 cattle (February 1979) and 24 cattle (April 1979), following a severe winter and a die-off of cattle. Several hundred cattle died on or near the study area that winter (John Winter, Bureau of Land Management, Rock Springs, Wyoming, pers. comm.), while we could confirm only 10 horse deaths.

Percent occupancy of vegetation types changed seasonally for both horses and cattle. On a yearly basis most of the horses and cattle were found in the sagebrush-grass type (56\% of the study area), but peak occupancy was in different seasons for horses and cattle. Feral horse use of sagebrush-grasslands was greatest during the fall and winter (Fig. 1) and was concentrated in the northern and eastern portions of the study area, which were only rarely used by cattle. Cattle use of this type peaked in summer and fall (Fig. 2) and was concentrated in the western and southern portion of the study area. Feral horses used the saltbush-winterfat type (17\% of the study area) in late spring and early summer (Fig. 1), but no similar cattle use was seen at any time of the year. Cattle use of the rabbitbrush subtype of the sagebrush-grassland type (10\% of the

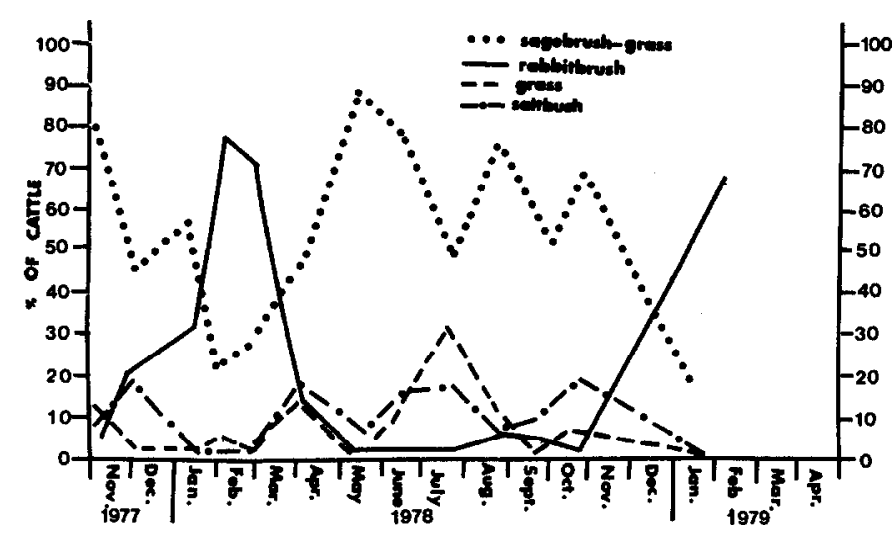

Fig. 2. Percent of cattle in vegetation types during survey flights.

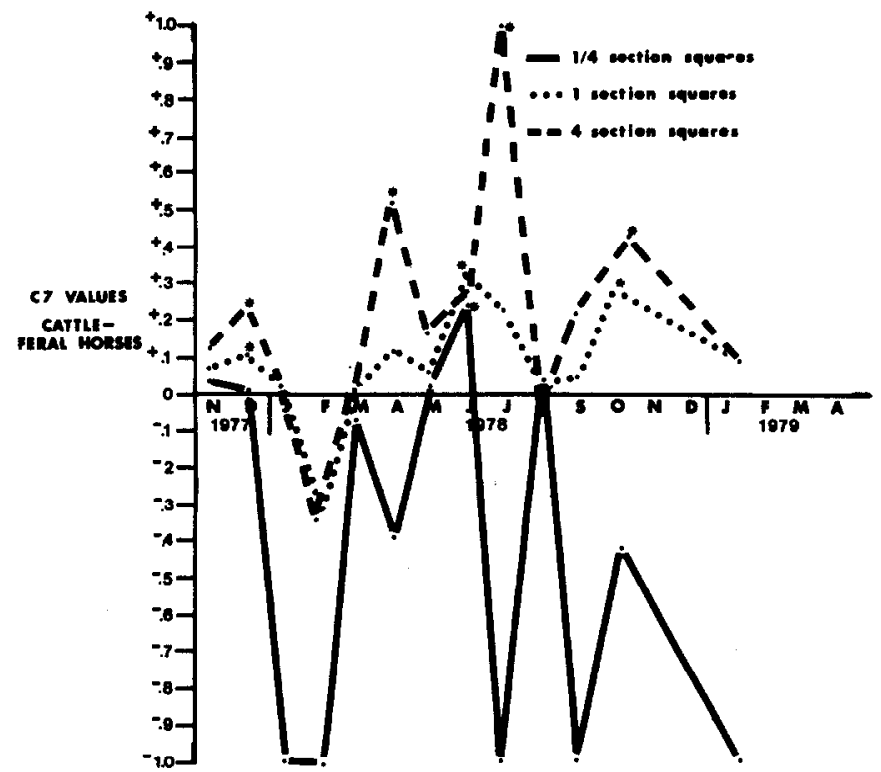

Fig. 3. C7 values, cattle association with feral horses for 3 grid sizes.

study area) increased dramatically each winter of the study (Fig. 2). The feral horses did not show any strong peaks in occupancy of the rabbitbrush subtype. Use of grass types by horses may be underrepresented, since horses often moved into the grasslands south of Fourth of July Well (S21, R100W, T23N) after drinking at dusk and moved out of those areas at dawn on their way to drink. This may be important in estimating grazing use, because Keiper (1980) found $55 \%$ of hours of darkness were spent grazing by Assateague Island ponies.

Feral horse occupancy of areas within $1.6 \mathrm{~km}$ of ridges $(66 \%$ of the study area) (Fig. 4) increased each winter. Cattle did not demonstrate similar affinity for areas near ridges. The small increase in horse use of areas near ridges in July and August is caused by use of areas within the dune fields and a hill near a water well. This may represent the use of ridges and associated winds for cooling. Although no seasonal use pattern for areas near ridges is apparent for cattle (Fig. 4), regressions of the average distance to ridges for both cattle and feral horses with the 7-day average temperature were significant $(p \leq 0.05)$. The 2 regressions were significantly different, with horses always predicted to be closer to ridges than cattle. The $r^{2}$ was low for the cattle regression but increased when wind speed data and 7-day average temperature were regressed with average distance to ridges (Table 1). However, these data were available for only 9 flights. A number of other weather variables had significant $(p \leq 0.05)$ regressions with the average distance of cattle or horses from ridges or water (Table 1), but 7-day average temperature was the most important single variable in each case for the full data set. Snow depth and temperature both showed significant relationships with the average distance of horses from ridges.

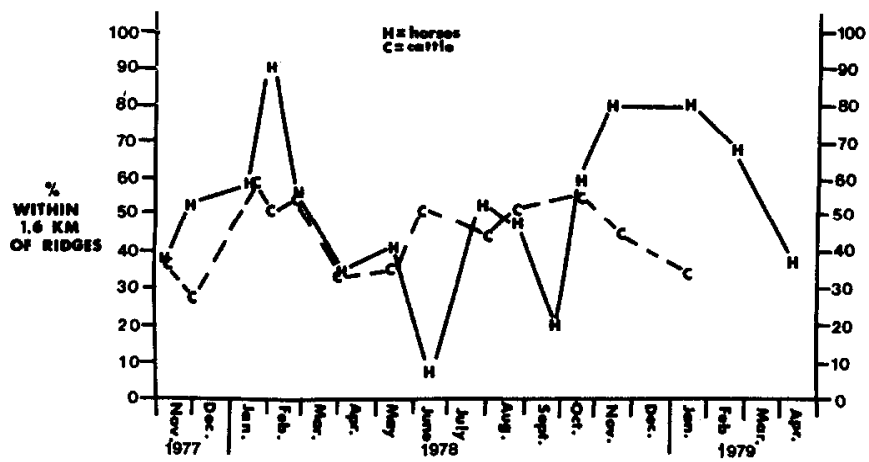

Fig. 4. Percent of cattle and feral horses within $1.6 \mathrm{~km}$ of ridges during survey flights. 
Table 1. Weather variables in significant regressions with the average distance of cattle and feral horses from ridges in the Red Desert.

\begin{tabular}{|c|c|c|c|}
\hline Y variable & $\mathrm{X}$ variables & $r^{2}$ & Level of significance \\
\hline Average distance of cattle from ridges & $\begin{array}{l}\text { 7-day average temperature } \\
\text { 2-day average temperature } \\
\text { wind speed } 1 \\
\text { 7-day avg. temperature and wind speed } \\
\text { 7-day avg. snow depth and wind speed' } \\
\text { Avg. temperature day of flight and wind speed' }\end{array}$ & $\begin{array}{l}.43 \\
.32 \\
.58 \\
.80 \\
.75 \\
.71\end{array}$ & $\begin{array}{l}.05 \\
.05 \\
.05 \\
.01 \\
.05 \\
.05\end{array}$ \\
\hline Average distance of horses from ridges & $\begin{array}{l}\text { 7-day average } \\
\text { 2-day average temperature } \\
\text { average temperature day of flight } \\
\text { 7-day average snow depth } \\
\text { 7-day maximum snow depth } \\
\text { 7-day avg. snow depth, and } 7 \text { day avg. temperature } \\
\text { 7-day max. snow depth, and } 7 \text { day avg. temperature } \\
\text { 7-day average temperature and wind speed' }\end{array}$ & $\begin{array}{l}.76 \\
.63 \\
.51 \\
.47 \\
.41 \\
.77 \\
.77 \\
.83\end{array}$ & $\begin{array}{l}.001 \\
.001 \\
.01 \\
.01 \\
.05 \\
.001 \\
.001 \\
.001\end{array}$ \\
\hline
\end{tabular}

'Data limited to flights when wind speed data were available. Regression equations will be supplied by the author on request. Only variables from multiple regressions with $r^{2}$ greater than the highest $\boldsymbol{r}^{2}$ for a single variable are shown.

Availability of drinking water is an important factor in the habitat at selection of both cattle and feral horses in the Red Desert. Both species show a strong seasonal use of areas within 4.8 $\mathrm{km}$ of water sources $(59 \%$ of the study area) (Fig. 5). Use of areas distant from water during late fall, winter, and early spring seems more related to vegetation type than to actual distance from water. On all 3 flights (February 3 and 24, 1978, and January 1979) when most cattle were more than $4.8 \mathrm{~km}$ from water sources, the majority of cattle were in the rabbitbrush subtype (Fig. 3). Ninety-one percent of the rabbitbrush subtype is more than $4.8 \mathrm{~km}$ from any water source. The significant positive coefficients of association between cattle and feral horses in April, June, and July (Fig. 3) can probably all be attributed to the association of both species with water sources (Fig. 6). Horses and cattle did not show a significant association with areas near water sources in May of 1978, probably because of the snow and cold that month, which caused a return to winter habitat use patterns.

Both cattle and feral horse distances from water are most strongly correlated to the 7-day average temperature. However, temperature, snow depths and wind speed all correlated with the average distance of horses and cattle from water (Table 2).

\section{Discussion}

Cattle and feral horse habitat use patterns in the Red Desert reflect the same 3 needs Welsh (1975) found important: food, water, and cover.

Several authors reported that the availability of water affects the distribution of feral horses (Green and Green 1977, Hansen 1976, Keiper 1976, Pellegrini 1971, Welsh 1975), cattle (Arnold and Dudzinski 1978, Cook 1966, Valentine 1947) and pronghorn (Antilocapra americana) (Sundstrom 1968 and Taylor 1974). Similarly I found that cattle and horses were generally within $4.8 \mathrm{~km}$ of water sources during the summer (Fig. 5). When cattle, pronghorn, and feral horses concentrate on the same water sources, 1 have observed direct competition for water. As long as water was plentiful at a source, no interspecific aggression was seen. When water was scarce, up to 197 horses used a single well in a day, and up to 119 horses were counted at a well at one time. Under those conditions horses waited up to 5 hours to drink, and inter- and intraspecific competition was at times intense (Miller and Denniston 1979). It was also common to find 50 to 100 cattle concentrated at a water hole. While horses and cattle forced each other from water at different times, pronghorn were displaced from waterholes in each observed encounter with horses. Pronghorn of ten came to a waterhole, walked around the concentration of horses and left, only to return shortly and repeat the behavior. When there was enough room at a waterhole for pronghorn to drink without getting closer than $3 \mathrm{~m}$ to a horse or cow, they drank freely. The presence of

Table 2. Weather variables in significant regressions with the average distance of cattle and feral horses from water sources in the Red Desert.

\begin{tabular}{|c|c|c|c|}
\hline Y variable & $\mathrm{X}$ variables & $r^{2}$ & Level of significance \\
\hline Average distance of cattle from water sources & $\begin{array}{l}\text { 7-day average temperature } \\
\text { 2-day average temperature } \\
\text { 7-day maximum snow depth } \\
\text { 7-day average snow depth } \\
\text { average temperature day of flight } \\
\text { 7-day avg. snow depth and 7-day avg. temperature } \\
\text { 7-day max. snow depth and 7-day avg. temperature } \\
\text { 2-day avg. temperature and 7-day max. snow depth }\end{array}$ & $\begin{array}{l}.64 \\
.51 \\
.50 \\
.49 \\
.34 \\
.73 \\
.69 \\
.65\end{array}$ & $\begin{array}{l}.01 \\
.01 \\
.01 \\
.01 \\
.05 \\
.01 \\
.01 \\
.01\end{array}$ \\
\hline Average distance of horses from water sources & $\begin{array}{l}\text { 7-day average temperature } \\
\text { 2-day average temperature } \\
\text { average temperature day of flight } \\
\text { 7-day average snow depth } \\
\text { 7-day maximum snow depth } \\
\text { 7-day avg. snow depth and 7-day avg. temperature } \\
\text { 7-day max. snow depth and 7-day avg. temperature } \\
\text { 14-day total precipitation and 7-day avg. temp. } \\
\text { 30-day total precipitation and 7-day avg. temp. } \\
\text { 7-day avg. snow depth and wind speed } \\
\text { avg. temperature day of flight and wind speed }\end{array}$ & $\begin{array}{l}.68 \\
.53 \\
.50 \\
.45 \\
.39 \\
.70 \\
.69 \\
.69 \\
.69 \\
.75 \\
.73\end{array}$ & $\begin{array}{l}.001 \\
.001 \\
.001 \\
.01 \\
.05 \\
.001 \\
.001 \\
.001 \\
.001 \\
.01 \\
.01\end{array}$ \\
\hline
\end{tabular}

'Data limited to flights when wind speed data were available. Regression equations will be supplied by the author on request. Only variables from multiple regressions with $r^{2}$ greater than the highest $r^{2}$ for a single variable are shown. 


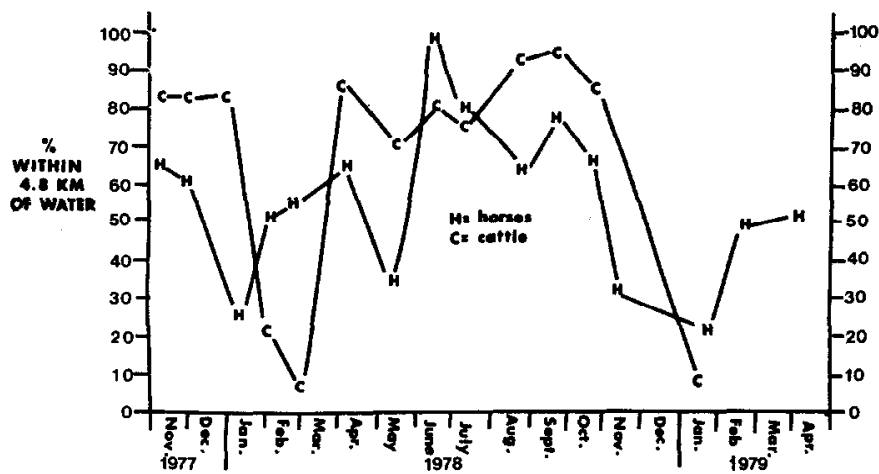

Fig. 5. Percent of cattle and feral horses within $4.8 \mathrm{~km}$ of water sources during survey flights.

horses at waterholes did not prevent either sage grouse (Centrocercus urophasianas) or coyotes (Canis latrans) from drinking.

Selection of areas distant from water in winter may be related to the availability of cover and availability of forage which was not used in summer. Since cattle, feral horses, and pronghorn (Sundstrom 1968, Taylor 1974) are all associated with areas near water in summer, it is reasonable to expect areas distant from water to have more available forage in winter. More forage may also be available along ridges than elsewhere in the Red Desert in the winter because the wind blows snow off areas near the tops of ridges. During winter flights we observed both cattle and horses taking cover from the wind behind ridges. Ridges are virtually the only cover for large animals in this section of the Red Desert.

Other authors have found wind cover to be important to cattle (Willms 1979) and to feral horses (Welsh 1975). Salter and Hudson (1978) also suggested that shelter might be important to feral horses during more severe winter periods in Alberta. Also, Bruns (1977) reported pronghorn in winter selected microhabitats having lower wind velocities and softer snow. Elk (Cervus celaphus) are known to select against deep snow (Leeger and Hickey 1977), and so may select from windblown ridges. All the elk we counted during the January (83 elk) and February (52 elk) 1979 flights were within $1.6 \mathrm{~km}$ of ridges. Selection of protected microclimates may be an energy conservation mechanism for ungulates (Malechek and Smith 1976). Selection for areas of reduced wind and shallow or soft snow may have accounted for the overlap in use areas of horses, cattle, pronghorn, and elk in the winter of 1978-79.

Olsen and Hansen (1977) found that the diets of cattle and feral horses in the Red Desert overlapped most in the fall (69\% diet similarity) and summer (61\% diet similarity) and least in the winter (21\% diet similarity) and spring (28\% diet similarity). Data from this study show that cattle and feral horses are selecting different vegetation types in the summer and winter and similar vegetation types in spring and fall. Because cattle and feral horses select similar vegetation types and foods in fall (Olsen and Hansen 1977), I believe direct competition for forage may exist in the fall between cattle and feral horses in the Red Desert. The coefficient of association for cattle and horses (Fig. 3) is positive and significant in December of 1977 and in October of 1978 and supports this assertion. Salter and Hudson (1980) similarly suggested that forage competition between cattle and feral horses might be occurring during autumn in Alberta.

Because of the dissimilarity of diet in the spring, dissimilarity of vegetation types used in summer and dissimilarity in both diet and vegetation types used in winter, I believe direct competition for forage between cattle and feral horses is less likely in those sea sons.

\section{Management Implications}

- Competition for water between feral horses, cattle, and pronghorn appears to be serious in dry years for a short time at specific wells. Reductions of horse numbers are suggested at wells where large numbers of horses congregate and use all of the water flowing from the well. These reductions would benefit feral horses, livestock, and wildlife and need not be large to be effective.

Winter ranges of feral horses in the Red Desert are characterized by proximity to ridges and distance from water sources. For this reason, creating new water sources near ridges to relieve summer competition for water could increase competition for forage that horses use in winter. Because these ridges are also used by elk and pronghorn in severe winters, there is a double reason not to create water sources near ridges.

\section{Literature Cited}

Amold, G.W., and M.L. Dudzinski. 1978. Ethology of Free-Ranging Domestic Animals. Elsevier Scientific Publ. Co.. New York

Bailey, R.G. 1978. Description of the Ecoregions of the United States. USDA, Forest Service, Intermountain Region, Ogden, Utah.

Bruns, E.H. 1977. Winter behavior of pronghorns in relation to habitat. $J$. Wildl. Manage. 41:560-571.

Bureau of Land Management. 1978. Final Environmental Statement: Proposed Domestic Livestock Grazing Management Program for the Sandy Area. USDI, Bureau of Land Management, Rock Springs Wyo. Vol. 1 .

Cole, L.C. 1949. The measurement of interspecific association. Ecology 30:411-424.

Cook, C.W. 1966. Factors affecting utilization of mountain slopes by cattle. J. Range Manage. 19:200-204.

Frei, M.N., J.S. Peterson, and J.R. Hall. 1979. Aerial census of wild horses in western Nevada. J. Range Manage. 32:8-11.

Gibbens, R.P. 1972. Vegetation pattem within northern desert shrub communities. Ph.D. Thesis, Univ. Wyoming, Laramie.

Green, N.F., and H.D. Green. 1977. Wild horse population of Stone Cabin Valley, Nevada: A preliminary report. p. 59-65 In: Proc. National Wild Horse Forum. Coop. Exten. Serv., Univ. of Nevada, Reno.

Hansen, R.M. 1976. Foods of free-roaming horses in southem New Mexico. J. Range Manage. 29:347.

Hansen, R.M., R.C. Clark, and W. Lawhom. 1977. Foods of wild horses, deer, and cattle in the Douglas Mountain area, Colorado. J. Range Manage. 30:116-118.

Hocking, R.R., and R.N. Leslie. 1967. Selection of the best subsets in regression analysis. Technometrics 9:531-540.

Hubbard, R.E., and R.M. Hansen. 1976. Diets of wild horses, cattle and mule deer in the Piceance Basin, Colorado. J. Range Manage. 29:389. 392.

Keiper, R.R. 1976. Social organization of feral ponies. Proc. Penn. Acad. Sci. 50:69-70.

Keiper, R.H. 1980. Nocturnal activity patterns of feral ponies. J. Mammals. 61:116-118.

Leeger, T.A., and W.o. Hickey. 1977. Elk-snow-habitat relationships in Pete King drainage, Idaho. Idaho Dep. Fish and Game, Wildlife Bull. \#6.

Malechek. J.C., and B.M. Smith. 1976. Behavior of range cows in response to winter weather. J. Range Manage. 29:9-12.

Miller, R., and R.H. Denniston, II. 1979. Interband dominance in feral horses. Z. Tierpsychol. 51:41-47.

NOAA. 1977. Climatological Survey, Annual Data Summary, Wyoming. 85(13). U.S. Dep. Comm., Nat. Oceanic and Atmospheric Admins., Nat. Climatic Center, Asheville, N.C.

NOAA. 1978. Climatological Survey, Annual Data Summary, Wyoming. 86(13). U.S. Dept. Comm., Nat. Oceanic and Atmosperhic Admin., Nat. Climatic Center, Asheville, N.C.

NOAA. 1979. Climatological Data, Wyoming. 87(1), (2), (3), \& (4). U.S. Dept. Comm., Nat. Oceanic and Atmospheric Admin. Nat. Climatic Center, Asheville, N.C.

Olsen, F.W., and R.M. Hansen. 1977. Food relations of wild free-roaming horses to livestock and big gamc, Red Descrt, Wyoming. J. Range Manage. 30:17-20.

Pellegrini, S.W. 1971. Home range, territoriality and movement patterns of wild horses in the Wassuck Range of western Nevada. M.S. Thesis, Univ. Nevada, Reno.

Salter, R.E. 1978. Ecology of feral horses in western Alberta. M.S. Thesis, Univ. Alberta. Edmonton.

Salter, R.E., and R.J. Hudson. 1978. Habitat utilization by feral horses in western Alberta. Le Naturaliste Canadien 105:309-321.

Salter, R.E. and R.J. Hudson. 1979. Feeding ecology of feral horses in western Alberta. J. Range Manage. 32:221-225.

Salter, R.E., and R.J. Hudson. 1980. Range relationships of feral horses with wild ungulates and cattle in western Alberta. J. Range Manage. 33:266-271. 
Storrar, J.A., R.J. Hudson, and R.E. Salter. 1977. Habitat use behavior of feral horses and spatial relationships with moose in central British Columbia. Syesis 10:39-44.

Sundstrom, C. 1968. Water consumption-by pronghorn antelope and distribution related to water in Wyoming's Red Desert. Proc. Antelope States Workshop. 3:39-47.

Taylor, E. 1974. Plant availability versus utilization by pronghorn antelope on the Red Desert of Wyoming. Proc. Antelope States Workshop 6:95103.
Valentine, K.A. 1947. Distance from water as a factor in grazing capacity of rangeland. J. For. 45:749-754.

Vavra, M., and F. Sneva. 1978. Seasonal diets of five ungulates grazing the cold desert biome. Proc. Internat. Rangeland Conf. 1:435-437.

Welsh, D.A. 1975. Population, behavioral and grazing ecology of the horses of Sable Island, Nova Scotia. Ph.D. Thesis, Dalhousie Univ.

Willms, W., A. McLean, R. Tucker, and R. Ritcey. 1979. Interactions between mule deer and cattle on sagebrush range in British Columbia. $J$. Range Manage. 32:299-304. 